\title{
The Best Practices of Human Rights (ATHam) Programme in Selected Secondary SCHOOLS IN MALAYSIA
}

\author{
Chang Lee Hoon \\ Jane Teng Yan Fang \\ Stefan Bucher \\ Nurhuda bt Basiran \\ Nafisah Ilham Hussin \\ Siti Norainizahhafizah bt Boyman \\ Sultan Idris Education University Malaysia
}

\begin{abstract}
AвSTRACT: The World Programme for Human Rights Education (2005 - ongoing), set up by United Nations General Assembly and coordinated by the Office of the United Nations High Commissioner for Human Rights (OHCHR) in partnership with the United Nations Educational, Scientific and Cultural Organization (UNESCO) seeks to promote a common understanding of basic principles and methodologies of human rights education, to provide a realistic framework for action, and to strengthen partnerships and cooperation from international to grass-root levels. Aligned with the World Programme for Human Rights Education, the Human Rights Commission of Malaysia (SUHAKAM) in partnership with the Ministry of Education Malaysia implemented the first phase of the Best Practices of Human Rights programme, known as the ATHAM programme in five selected secondary schools in Malaysia. A research study using mixed method sequential exploratory design was conducted to examine the schools' experiences with the ATHAM programme in terms of participation, implementation and challenges. The respondents consisted of school administrators, teachers and pupils; in total, 103 respondents were interviewed and 798 respondents answered the questionnaires. Drawing from these schools' experiences, this article discusses the best practices of human rights or ATHAM programme in selected secondary schools in Malaysia.
\end{abstract}

\section{Introduction}

The Universal Declaration of Human Rights (UDHR) clearly stipulated that human rights education (HRE) is an integral part of the right to education and that "education shall be directed to the full development of the human personality and to the strengthening of respect for human rights and fundamental freedoms" (Article 26.2). The United Nations Educational, Scientific and Cultural Organization (UNESCO) expressed that HRE should "contribute to the development of individuals who possess the skills to interact in a society ... providing students with the abilities to accompany and produce societal changes ... as a way to empower people, improve their quality of life ... participate in decision making processes leading to social cultural and economic policies" (UNHCR, 2009).

HRE in schools is important for democratic citizenship, and the education for mutual respect and understanding as it promotes equality, empowerment and participation, as well as conflict prevention and resolution. It entails conveying ideas and information to students on the importance of human rights, and nurturing the values and attitudes that lead to the support of these rights and the way they live. HRE will help to develop a society where the human rights of all are respected, protected and fulfilled (cf. OSCE, 2009).

In Malaysia, HRE in schools is seen to be important as there is a growing concern on some school practices that contradict the UNDHR and the Convention on the Rights of the Child (CRC). For instance, the Education Act 1996 states that caning is allowed but to male students only. In

a Correspondence can be directed to: changlh@fsk.upsi.edu.my 
using caning as a disciplinary measure, schools are to adhere to the disciplinary procedures set by the Ministry of Education. Whilst disciplinary measures are deemed to be justifiable in Malaysian schools, there were some parents and the general public who voiced their concern on the use of caning as effective measure and their fear of abuse of power (SUHAKAM, 2006). A research study on knowledge and practice of human rights in secondary schools was conducted by SUHAKAM in 2003. It was a survey of which 5,754 secondary students, 2,132 teachers and 142 administrators from 40 urban and rural schools answered the questionnaires. The results showed that majority of the students, school administrators, and teachers favoured caning of male students. In addition, more than $60 \%$ of the students and $50 \%$ of the teachers stated that discrimination was practised in their schools. Discrimination was often based on gender, race, religion, social standing and economic status. For the students, discrimination based on academic ability was common (SUHAKAM, 2006).

It was often reported in the local media of the students' delinquent behaviour that reflect violations of human rights. Gang fights, extortion, bullying, vandalism and molestation in schools are some incidences of students' misbehaviour and disciplinary problems. There were also reported cases of teachers and school administrators who deprived the students of their rights such as teachers who humiliated and disallowed students to express their ideas and views freely (SUHAKAM, 2006). In addition there were reported incidences in school of sexual and physical abuses of the children by the adults. Such incidences in the school threaten the students' security and well-being to learn in a safe environment. Perhaps through HRE, incidences on violations of the children's rights could be lowered. All teachers and students would also be more aware of their rights and the rights of others and subsequently they can become more understanding, responsible, and respectful and accept each other's differences as individuals with rights. This is particularly important in a multiracial and religious society in Malaysia.

On 10 December 2004, the General Assembly of the United Nations proclaimed the World Programme for Human Rights Education (HRE) to advance the implementation of human rights education programmes in all sectors (UNESCO, 2006). The Office of the United Nations High Commissioner for Human Rights (OHCHR) provides global coordination of the World Programme. Building on the achievements of the United Nations Decade for Human Rights Education (1995-2004), the World Programme for HRE seeks to promote a common understanding of basic principles and methodologies of HRE, provide a concrete framework for action and strengthen partnerships and cooperation from the international level down to the grass roots. It states that,

Human rights education should not only be theoretical but should also provide opportunities for
young people to develop and practice the skills to respect human rights and citizenship through
"school life", i.e. all aspects of school as a living, social environment with its collective rules,
interpersonal conflicts, time and opportunities for co-operation, and through opportunities for
spontaneous initiatives by the pupils outside the actual teaching activities. (UNESCO, Human
rights education, n.d.)

Unlike the specific time frame of the UN Decade for HRE, the World Programme for HRE is structured in consecutive phase so as to further focus national HRE efforts on specific sectors/issues. The first phase (2005-2009) focused on HRE in the primary and secondary school systems. The second phase (2010-2015) focuses on HRE for higher education and on human rights training programmes for teachers and educators, civil servants, law enforcement officials and military personnel. The First Phase of the Plan of Action of the World Programme for HRE (2005-2007) was adopted by all Member States of the United Nations General Assembly on $14^{\text {th }}$ July 2005 . The Human Rights Commission of Malaysia widely known by its acronym SUHAKAM (Suruhanjaya Hak Asasi Manusia) states that Malaysia, being a UN Member State, has the responsibility to implement the Action Plan of the World Programme for HRE (SUHAKAM, 2009). Hence under the Human Rights Education in School committee of the Education Working Group, SUHAKAM undertook a holistic programme on Best Practices of Human Rights (Amalam Terbaik Hak Asasi Manusia) in schools, known as ATHAM programme (SUHAKAM, 2009). 
The Human Rights Commission of Malaysia (SUHAKAM) was established in 1999 by an Act of Parliament, the Human Rights Commission of Malaysia Act (Act 597). Under the Act, SUHAKAM is assigned among others, "to promote awareness of and provide education in relation to human rights" (Section 4(1)). On this basis, education on human rights is considered as a fundamental responsibility of SUHAKAM. One of the working committees of SUHAKAM is the Human Rights Education and Promotion Working Group (EWG). It was set up to promote among others HRE for all members of society and collaborate with government agencies, non-governmental organisations and civil society in the implementation of HRE programmes (SUHAKAM, Education and Promotion Working Group, n.d.).

SUHAKAM has produced several reports and research relevant to HRE, such as the Report on Access to Education in Malaysia (n.d.), the Report of the Roundtable Discussion Convention on the Rights of the Child (2005), Human Rights Lesson Plan for Southeast Asian schools (n.d.), the Human Rights Approach on the Millennium Development Goal - Goals 2: Achieve Universal Primary Education (2006), and the Research on Knowledge and Practice of Human Rights in Secondary Schools (2006). In addition SUHAKAM has also conducted in collaboration with various government agencies, including the Ministry of Education many HRE seminars and workshops on UNDHR and CRC for the various sectors of the society inter alia school students, university students, teachers, lecturers, education officers, orang asli (indigenous) groups, police, and other government enforcement staff (SUHAKAM Education and Promotion Working Group). One of the recent education programmes implemented by SUHAKAM in 2009 is the ATHAM programme which is the focus of this research study.

\section{The Best Practices of Human Rights (ATHAM) Programme}

The main aim of the best practices of human rights or ATHAM programme is to "create and practice a culture of human rights in school responsibly for continual social harmony and living". The objectives of the programme are to: (i) encourage students and all school stakeholders to give emphasis to and take action towards the practice of human rights; (ii) inculcate mutual respect and responsibility towards human rights and its practices in daily lives; (iii) increase understanding and the practice of human rights towards harmony for all; (iv) encourage pupils and teachers to give emphasis to aspects of human rights in the planning and implementation of school activities; ( $v$ ) share experiences on human rights practices in school with the local community; and (vi) strengthen the relationships and interactions among students regardless of race, religion or gender. (SUHAKAM, 2009. Unofficial translation by the researchers).

In the first phase of the ATHAM programme, five secondary schools in the Federal Territory of Kuala Lumpur, Selangor, Perak, Negeri Sembilan and Melaka were selected. The five schools were nominated by the various states' department of education and they gave their consent to participate in the programme. SUHAKAM provided the schools with a guideline on the ATHAM programme as well as documents on CRC and UNDHR. The ATHAM programme guideline consisted of suggestions on the whole-school approach in the implementation of the programme in school. The suggestions included forming an ATHAM implementation committee; and selection of any areas of the wholeschool approach on HRE either in the curriculum, co-curriculum, school management or students' affair. In the guideline, schools were also requested to determine the articles in the CRC and UNDHR that the school would like focus on when implementing the ATHAM programme. SUHAKAM with the collaboration of the Ministry of Education conducted a workshop to facilitate the five participating schools to outline their action plans on the ATHAM programme.

It is to be noted that prior to the ATHAM programme, HRE is integrated into the curriculum and co-curriculum in Malaysian schools. It is integrated into the school curriculum through the Moral Education (ME), Islamic Education (IE), and Civics and Citizenship Education (CCE) subjects. The ME subject is a compulsory core subject for all non-Muslim students whilst the Muslim students are required to take the IE subject. The core of the ME syllabus is the 36 values that were drawn from various religions, culture and traditions of Malaysian society. The 36 values are categorised 
into seven major learning areas of study. These are values related to self-development, family, environment, patriotism, human rights, peace and harmony. By learning all these values, the Ministry of Education aims to develop responsible individuals who are equipped with values that are acceptable to Malaysian society and aligned to universal values. The CCE subject is a compulsory subject for all students. The core of CCE is to educate students on their rights with responsibilities, multiculturalism, and harmonious living in Malaysia's plural society.

Co-curricular activities are compulsory at upper primary (Year 4 to Year 6 ) and at all secondary (Form 1 to Form 5) levels. All students must participate in at least two activities, of which one must be sports-related. Co-curricular activities are categorised as uniformed groups, performing arts, clubs and societies, and sports and games. These activities provide opportunities for students to develop their interest, talent and aptitude outside the classroom. Students are generally given the right to choose the types of clubs, societies or games that they would like join. Competitions, special projects and programmes are also organised by schools such as Sports Day, Co-curriculum Day, Quran Reading Competition, Career Day, National Day and Anti-Smoking Campaigns.

However, SUHAKAM anticipated that with the ATHAM programme, schools would adopt best practices of human rights by implementing the whole-school approach in HRE as envisaged in the World Programme for HRE. In other words, the practices of human rights should not be reduced to merely learning of human rights content in the classrooms but should also include opportunities for students to develop and practise human rights in their daily interactions with others, both inside and outside the classroom, within the school environment. It is in this context that the best practices of human rights programme or ATHAM programme is considered to be a HRE programme and the terms the best practices of human rights programme and the ATHAM programme are used interchangeably. This article draws on the study conducted on the selected five secondary schools' experiences with the best practices of human rights programme in Malaysia. The study was funded by SUHAKAM to a team of researchers from Sultan Idris Education University, Malaysia.

\section{Research Methodology}

The main purpose of the study was to explore the five selected secondary schools' experiences with the SUHAKAM's Best Practices in Human Rights (ATHAM) programme. It focussed on the participation, challenges, implementation, benefits, and future plans of the schools with the ATHAM programme. The study used mixed method sequential exploratory design (Creswell, 2008) to examine the schools' experiences with the ATHAM programme. The first phase was the collection and analysis of qualitative data using both in-depth and focus group interviews, as well as document analysis. This was then sequentially followed by the collection and analysis of quantitative data using questionnaires that were constructed from the qualitative data. Both the qualitative and quantitative data were then consolidated by using strengths, weaknesses, opportunities and threats (SWOT) analysis to draw conclusions on the study on the best practices of human rights programme in Malaysian secondary schools. As the HRE activities on the ATHAM programme were conducted outside the classroom, and time constraint in conducting this research study, no classroom observations were made. Hence the findings in this study on the best practices of human rights programme did not include human rights practices in the classroom environment.

\section{Respondents}

The respondents consisted of school administrators, teachers and pupils from the five selected secondary schools. A total of 103 respondents were interviewed and 798 respondents answered the questionnaires. The 103 respondents who participated in the interviews were five school principals, four senior assistants, five ATHAM coordinators, 21 teachers involved in the planning and implementation of ATHAM programme, 18 teachers not involved, 28 pupils involved, and 22 pupils not involved in the planning and implementation of the ATHAM programme. The five ATHAM coorinators were appointed by the school principals and they were also the schools' counsellors. 
In-depth interviews were conducted with the school principles, senior assistants and the ATHAM coordinators whilst focus group interviews were conducted with the other teachers and the pupils. Out of a total of 798 respondents who participated in the survey 148 of them were teachers and the other 650 were students from the five participating schools. About $75 \%$ of the students who were interviewed and answered the questionnaires were between the ages of 16 to 18 years old and at upper secondary school level (Forms 4 to Form Six). They were randomly selected and consisted of those who were involved and those who were not involved in the planning and implementation of the HRE activities organised under the ATHAM programme.

\section{Instruments}

As this is a mixed method research design, qualitative and quantitative instruments were used to answer the research questions. The qualitative instruments consisted of a common interview protocol, guidelines on observations, and guidelines on documents. These standard protocols were used by all researchers so as to provide consistency in the data collection procedures at the five different sites. The interview protocol consisted of semi-structured questions for soliciting the experiences of the school principals, senior assistants, the ATHAM programme coordinator, the teachers and pupils who were involved and not involved in the planning and implementation of the ATHAM programme. The main interview questions focussed on seven areas, namely the respondents' involvement in the ATHAM programme, the conditions in their school they would like to improve human rights practices, and the challenges they faced in the ATHAM programme, the ways to overcome the challenges, the implementation, the benefits, and the future plans of the ATHAM programme in their school.

Two sets of questionnaires were then constructed to gather quantitative data. The first set of questionnaires was for the teachers, including the school administrators (principals and senior assistants), whilst the second set of questionnaires was for the pupils. All items in both sets of the questionnaires were similar except for the first section of the questionnaires which was on the background of the respondents, either as teacher or pupil. The items in the questionnaires were constructed based on the objectives of the ATHAM programme and identified themes and subthemes derived from qualitative data in this research study.

\section{Data Analysis}

The data analysis involved three stages. The first stage was the analysis of the qualitative data derived from the interviews, the observational notes and the documents obtained from the five schools. All taped interviews were fully transcribed. The qualitative data from the different groups of respondents (the school administrators, teachers and students) were then content analysed, using inductive and deductive analysis. Open and axial coding (Corbin and Strauss, 2008) were conducted to identify common themes and sub-themes. The second stage of data analysis entailed analysing the quantitative data obtained from the teachers' and students' questionnaires. Descriptive analyses were conducted using SPSS version 17.0 software. The final stage was the consolidation of the qualitative and quantitative data using strengths, weaknesses, opportunities, and threats (SWOT) analysis to identify the best practices of human rights or ATHAM programme among these five participating secondary schools.

\section{Findings and Discussion}

The best practices on human rights schools (ATHAM) programme in Malaysian secondary schools were drawn from the qualitative and quantitative data obtained from the five participating schools on the programme. It is acknowledged that the findings on the best human rights practices programme is limited to the experiences of the teachers (including the school principals or other school administrators) and students in these five secondary schools that participated in the ATHAM 
programme. However, the findings from this research study could provide some guidance to other schools in promoting human right practices programme in Malaysian schools.

\section{The Objectives of the ATHAM Programme}

Among the six objectives of the ATHAM programme (see page 5), the respondents, namely the school administrators, teachers and students in this research study indicated that the most important objective on the ATHAM programme was to strengthen relationships and interactions among the students, teachers and school administrators regardless of race, religion or gender (mean $=4.65$ ). This was followed by the objective to inculcate mutual respect towards human rights practices among the students, teachers and school administrators (mean $=4.64$ ) and the objective to increase understanding and the practices of human rights towards harmony for all (mean $=4.42$ ).

The perceptions of the teachers and students on strengthening relationships, mutual respect and understanding among students, teachers and school administrators from diverse background in human rights practices seemed to be aligned to the two main thrusts in Malaysia's educational goals of developing human capital development and national unity (Siow \& Chang, 2010). Furthermore, living in peace and harmony is important as Malaysia is a plural society, particularly in terms of race and religion. The 2010 population census showed that out of a total population of 28.3 million, 67.4 per cent were Bumiputera (consisting of 63.1 per cent Malay and other indigenous groups), 24.6 per cent Chinese, 7.3 per cent Indians and 0.7 percent others (such as Eurasians). Although Islam is the official religion and the most widely professed religion (61.3 per cent), 19.8 percent of the Malaysian citizens embraced Buddhism, 9.2 per cent Christianity and 6.3 per cent Hinduism (Department of Statistics Malaysia, 2012).

\section{Participation in the ATHAM Programme}

A culture of human rights practices in schools would imply that all pupils and teachers would need information on HRE. As ATHAM is a new HRE programme that is being introduced to encourage all students and teachers to practise human rights in their schools, it is important that information on human rights, particularly on UDHR and CRC be known to all. This is evident as the results of the study indicated that although schools participated in the programme as requested by their respective state department of education, there were some gaps in the dissemination of information on the programme to schools, teachers and students.

The teachers who attended the workshop on the ATHAM programme were not informed of the reasons for their participation. They attended the workshop as they were directed to do so by the school principals. In addition, it was mentioned that prior to their participation at the workshop they lacked knowledge on the UDHR and CRC. It is of interest to note that the school administrators said that they informed all teachers and students of the ATHAM programme at staff meetings and school assemblies. However, teachers and students who were not involved in the planning and implementation of the programme mentioned that they did not get the information on ATHAM from their schools. The quantitative findings showed that the main source of information on human rights and the ATHAM programme to the teachers was the local media and internet (mean = 3.83), but to the students their main source of information was their teachers (mean $=3.57$ ). However the teachers and students who were involved in the planning and implementation of the ATHAM programme claimed that they knew more about UDHR and CRC as a result of their participation in the programme.

It was observed by the researchers during the school visits that all the five schools did attempt to disseminate information about UDHR and CRC as well as the ATHAM programme in the school bulletin boards, along the school corridors or in specially assigned locations within the school compound. Based on the observations, interviews and responses on the questionnaires, it can be implied that there is a need to encourage more active participation of all teachers and students in the school's 
ATHAM programme. Wider dissemination of the human rights practices in schools through the local media and the internet would benefit the teachers and subsequently the students as the teachers are an important source of information. Furthermore as emphasised by the teachers and students during the interviews as well as observations of the researchers, leadership role of the principals, specifically in terms of commitment, support and being a role model of human rights practices, is crucially important. This is to ensure that the human rights practices or the ATHAM programme in the school are carried out by the teachers and students.

\section{Improving Human Rights Practices in School}

The teachers and students indicated that human rights practices in their schools could be further improved. The qualitative findings showed that there were four areas that the respondents wanted their schools to improve on human rights practices, namely on the education and learning system, the students' discipline and developing them to become better individuals, the school environment, and knowledge on human rights. In terms of improving the education and learning system, a teacher said that all children have a right to learn and that schools have no right to stop them from schooling. However, it was "the parents who did not want their children to attend school". A discipline teacher said that if students "have made mistakes, they should know the disciplinary process". A school principal said that through the ATHAM programme, she hoped that the teachers and students could improve themselves to become "role models" for other students and that it would make them "better individuals". In terms of improving knowledge on human rights, the school principal and the ATHAM coordinator from one school said that through the ATHAM programme, the students would know their right to quality education and their right to participate in co-curriculum activities. Another ATHAM coordinator voiced out that "there seemed to be not much connection between knowledge and human rights practices as it is not formal curriculum."

The quantitative findings indicated that the teachers perceived that the improvement of human rights practices in their schools should be in the students' behaviour (mean $=4.34$ ) and the school environment (mean $=4.27$ ). This was followed by increasing the level of awareness on the human rights (mean $=4.20$ ) and including the human rights practices in the teaching and learning processes (mean $=4.11$ ). On the other hand, the students perceived that the improvement of human rights practices in their schools should be on increasing the level of awareness on the human rights (mean $=4.18$ ), followed by including human rights practices in the teaching and learning processes and in students' behaviour (each with mean $=4.14$ ), and finally changes in school environment (mean = 4.03) . Surprisingly, some teachers were either neutral (35.6\%) or agreed (26\%) that they believed human rights conditions in their schools cannot be changed (mean $=2.81$ ).

The results clearly indicated that whilst the teachers and school administrators seemed to focus on human rights practices in terms of students' behaviour, particularly in the school discipline, the students wanted to improve their knowledge on human rights. The teachers said that respecting the rights of others and obeying the school rules were clear indications of good human rights practices by the students. During the interviews, there was a general concern among the teachers on the implementation of human rights in school regarding a "balance between being realistic and idealistic" and that teachers "cannot give full freedom" to the students. Concerns were raised that if the students were to know of their rights it could lead to some "difficulties or undesirable behaviour".

\section{Implementing the ATHAM Programme}

All the five schools said that the SUHAKAM's officers, High Commissioners, and members of the SUHAKAM Human Rights Education in School committee visited their schools to assist them in planning, executing and monitoring the ATHAM programme. The study found that that the ATHAM programme was implemented in all the schools through special activities, co-curriculum and the school management particularly on students' discipline as shown in Table 1 below. 
Table 1: Schools' Action Plans on the ATHAM Programme

\begin{tabular}{|c|c|c|c|}
\hline Name of School & Action Plan Theme & Objective & Examples of ATHAM Activities \\
\hline School A & $\begin{array}{l}\text { Ambang } \\
\text { Kemerdekaan: } \\
\text { Cintai Negara Kita } \\
\text { (Emergence of } \\
\text { Independence: } \\
\text { Love our Country) }\end{array}$ & $\begin{array}{l}\text { 1. To uphold and practise } \\
\text { human rights principles } \\
\text { in respecting the right of } \\
\text { every person to protect } \\
\text { the wellbeing and welfare } \\
\text { of all in the school, } \\
\text { community and nation } \\
\text { 2. To create solidarity } \\
\text { among each other. }\end{array}$ & $\begin{array}{l}\text { Speeches by students during } \\
\text { school assemblies } \\
\text { Open discussions or Dialogues } \\
\text { between school principal and } \\
\text { students. } \\
4 \text {. Organisation of Prefects' Day } \\
\text { and Convention by the students. } \\
5 \text {. Display of information on UDHR } \\
\text { and CRC as well as issues on } \\
\text { human rights in "Laluan (Pathway) } \\
\text { ATHAM" and bulletin boards. }\end{array}$ \\
\hline School B & $\begin{array}{l}\text { Pemantapan } \\
\text { Disiplin } \\
\text { (Improving } \\
\text { Discipline) }\end{array}$ & $\begin{array}{l}\text { 1. To give awareness } \\
\text { to students their } \\
\text { responsibilities towards } \\
\text { the school and each other. } \\
\text { 2. To give awareness to } \\
\text { the students that their } \\
\text { actions are limited by the } \\
\text { school rules. } \\
\text { 3. To respect the freedom } \\
\text { among teachers and } \\
\text { students in promoting } \\
\text { peace and general well- } \\
\text { being of all. }\end{array}$ & $\begin{array}{l}\text { 1. A five-minutes slot on ATHAM } \\
\text { programme in school radio } \\
\text { 2. Information on UDHR and CRC } \\
\text { articles as well as current issues on } \\
\text { human rights in bulletin boards } \\
\text { 3. Students' suggestion box } \\
\text { 4. Participation of students in } \\
\text { running the election of prefects }\end{array}$ \\
\hline School C & $\begin{array}{l}\text { Program Jom Ke } \\
\text { Sekolah } \\
\text { (Come to School } \\
\text { programme) }\end{array}$ & $\begin{array}{l}\text { 1. To improving students' } \\
\text { attendance to school } \\
\text { 2. To have zero truancy }\end{array}$ & $\begin{array}{l}\text { 1. Quizzes and essay competitions } \\
\text { on HRE } \\
\text { 2. Mural painting on UDHR and } \\
\text { CRC articles on walls along the } \\
\text { school corridors }\end{array}$ \\
\hline School D & $\begin{array}{l}\text { ATHAM "Laluan } \\
\text { Hak Asasi Manusia" } \\
\text { (ATHAM's Pathway } \\
\text { to Human Rights) }\end{array}$ & $\begin{array}{l}\text { 1. To increase } \\
\text { understanding on human } \\
\text { rights among the school } \\
\text { citizens. }\end{array}$ & $\begin{array}{l}\text { 1. Quizzes and essay competitions } \\
\text { on HRE } \\
\text { 2. Co-curriculum carnival } \\
\text { 3. Display of UDHR and CRC } \\
\text { articles as well as current issues on } \\
\text { human rights in the "Pondok (Hut) } \\
\text { ATHAM" } \\
\text { 4. A five-minutes slot on the } \\
\text { ATHAM programme in school radio }\end{array}$ \\
\hline School E & $\begin{array}{l}\text { Headcount Barakah } \\
\text { (Acclaiming } \\
\text { Headcount) }\end{array}$ & $\begin{array}{l}\text { To develop students' } \\
\text { mental capability, } \\
\text { personality, talent and } \\
\text { physical ability to their } \\
\text { highest potentials. }\end{array}$ & $\begin{array}{l}\text { 1. Participation of students in } \\
\text { running the election of prefects } \\
\text { 2. Information on UDHR and CRC } \\
\text { articles as well as current issues on } \\
\text { human rights in bulletin boards }\end{array}$ \\
\hline
\end{tabular}

The activities organised under the ATHAM programme were found to be aligned to several articles in UDHR and CRC. For instance, UDHR Article 19 and CRC Article 13 (freedom of expression) were articulated in quizzes, speeches by students, open discussions between the school principal and students, and the students' participation in the running of elections of prefects; CRC Article 15 (freedom of association) and Article 31 (right to leisure, recreation and cultural activities) were articulated in co-curriculum carnival, facilities for musical and cultural activities, and Prefects' Dinner 
and Convention organised by the prefects themselves; UDHR Article 3 (right to live in the freedom and safety from harm) and CRC Article 28 (the right to an education which prepares him/her for an active, responsible life as an adult in a free society which respect others and the environment) were articulated in the enforcement of discipline as stipulated in the Ministry of Education Guidelines on School Discipline; CRC Article 17 (right to information) was disseminated through school radio, setting up of Pondok (Hut) ATHAM, Laluan (Pathway) ATHAM, and bulletin boards in open and accessible areas to all.

In sharing the experiences on the ATHAM programme, the ATHAM coordinators from two schools said that they slotted in the ATHAM programme in the school radio system every morning. The students would read an article in the UDHR or CRC of approximately five minutes and by doing so, the information on human rights would reach the whole school population and hence saved them time in disseminating the information. In elaborating the students' active participation in the prefects' election campaign such as acting as watchdog and setting up special human rights banners, the ATHAM coordinator from School E said that, "SUHAKAM told us that, if possible involve the students in decision-making. . . Election is not done by the teachers, but run by students and supported by form six teachers. Teachers are not involved, they only vote." The students in School A voiced their experiences and said that they distributed SUHAKAM's pamphlets on CRC and UDHR and promoted human rights to others. It was observed during the school visits that all the schools had adequate learning infrastructure and services such as counselling services, canteen, library, computer room, landscaped garden, rest areas, and bulletin boards that promoted and enhanced quality of learning in the school.

In the questionnaires, the teachers and students were asked on their views concerning the ways of implementing the ATHAM programme. The quantitative findings indicated that the teachers agreed that the ATHAM programme be implemented in special activities (mean $=4.22$ ), followed by co-curriculum activities, the school environment (each with mean $=4.18$ ) and lastly in the school curriculum (mean $=4.01$ ). The students also mostly agreed that the ATHAM programme were implemented in special activities (mean $=3.94$ ). This was followed by implementing the ATHAM programme in the school environment (mean $=3.93$ ), and in the co-curriculum (mean $=3.79$ ). Both teachers (mean $=4.01$ ) and students (mean $=3.36$ ) least agreed that the ATHAM programme be implemented in the curriculum. The students (mean $=3.15$ ) were less agreeable than the teachers (mean $=3.68$ ) that their school had succeeded in implementing the ATHAM programme.

Both the qualitative and quantitative findings in this study indicated that the implementation of the best practices of human rights programme seemed to be more towards informal than formal curriculum. In other words, the teachers and students were of the view that the programme be implemented through specific organised ATHAM activities, co-curriculum and the school environment rather than in the school subjects. This could be the case as the ATHAM programme is not a programme by the Ministry of Education but a programme introduced by the Human Rights Commission of Malaysia (SUHAKAM) and hence schools are not compelled to include the programme in the school curriculum. However, as expressed by one teacher that all ATHAM activities outside the classroom needed to be linked to teaching and learning because, "if we want to punish a student, the student may consider this be an abuse ... (so) we can include some topics on human rights in the Civic and Citizenship subject.

\section{Benefits of the ATHAM Programme}

The qualitative findings indicated that the teachers and students benefitted from the ATHAM programme in terms of increasing knowledge about human rights, the awareness of human rights practices, and the responsibilities of human rights practices. At the interview sessions with the students, the students in all five schools said that they received information on human rights from the school radio, bulletin boards, mural paintings and specially assigned areas such as the Pondok ATHAM and the Laluan ATHAM for as said by one student, "Now I know what UDHR and CRC are". 
A teacher commented that the ATHAM programme increased the students' knowledge on human rights which they learnt in Civic and Citizenship Education subject because "when they relate what they had learnt in the class with the (ATHAM) programme they will remember better. The quantitative results supported the qualitative data as the teachers (mean $=4.18$ ) and students (mean $=4.00$ ) indicated that the ATHAM programme had increased their knowledge on human rights.

Both teachers and students revealed that they were more aware of their rights, such as right to speak, right to choose their student leaders (election of prefects) as well as human rights practices in the school discipline process. For instance, a student mentioned that through the ATHAM programme, she learnt that SUHAKAM is a "department that protects human rights especially children's rights", while another student said that "we are children, we as persons have the right to speak". A teacher commented that the students were well aware that they have the right to get education for as commented, "generally when we go to class and say that if you are lazy to study, it is better that you go home and stop schooling. Then the student will say, "teacher, we have the right to learn" ... so looks like they know their right to education." One ATHAM coordinator commented that sometimes the teachers had to work over the weekends and after school hours till night time. He expressed that as employees, they have the right to rest and they have families too. The quantitative results supported the qualitative data as the teachers (mean $=4.16$ ) and students (mean $=4.01$ ) indicated that the ATHAM programme had increased their awareness of human rights practices.

The teachers were of the opinion that the ATHAM programme had benefitted the students as it had increased the students' awareness of their responsibilities, provided space for students to be creative and master leadership skills. For example, as said by a teacher that "every individual has a responsibility to teach human rights, to respect human rights". Two school administrators said that the events organised by the students such as the prefects' election programme and the prefects' day and convention provided opportunities for the students to lead. Another school administrator commented that if students were noisy in the classroom, the students should accept the punishment as they had violated the rights of other students. A teacher said that "every individual has a responsibility to teach human rights, to respect human rights". The quantitative results supported the qualitative findings as the teachers (mean $=4.07$ ) and students (mean $=3.90$ ) indicated that the ATHAM programme had increased their awareness on their rights with responsibilities towards self and others.

Although the ATHAM programme had benefitted the students, there were few voices of concern on implementing the ATHAM programme on human rights practices. A discipline teacher mentioned that human rights practices could be "abused by students to either lengthen or complicate the discipline process". A school administrator said that the ATHAM programme should be a "win-win situation" in which teachers give more rights to the students in terms of participation and practising "two-way communication" but at the same time the students should become more responsible and engage less in anti-social behaviours like bullying, vandalism and other problematic behaviours. Nonetheless, the teachers confirmed that the ATHAM programme had benefitted the students and teachers as "there is no discrimination between races; between excellent and weak students ... everyone has their own abilities. ATHAM can give them more confidence".

\section{Challenges and Constraints in Implementing the ATHAM Programme}

The teachers and students expressed that the ATHAM programme was important to their schools. However, they encountered several challenges and constraints when implementing the programme. One of the challenges the teachers faced was the lack of knowledge and misunderstanding of human rights particularly among the students. For instance, a teacher commented that when he discussed with the students in the class on what were right and wrong actions of the students, "they feel that they are always right. So, they still don't understand about human rights. Sometimes, they cannot accept why a teacher took action and punished them". This view was similarly expressed by another teacher when he said that "the students would not admit that what they did was wrong even though 
they were really wrong. The discipline teacher had to prove that they violated a school rule. So he had to work harder on that and sometimes he missed his class because of that".

The other challenges faced by the teachers and students were the heavy work load and the constraint of time in implementing the ATHAM programme. The teachers in all five schools who were involved in the planning and implementation of the ATHAM programme said that they felt "stressful" and that the programme was an "extra burden" as they had many other teaching and non-teaching duties and responsibilities that they had to do. The students in all five schools mentioned that apart from the classes and co-curricular activities, there were many other school activities that they had to participate and hence had limited time for the activities of the ATHAM programme. In addition, the teachers and school adminstrators faced difficulty in getting the support and cooperation from parents and students. In one of the schools, the teacher said that the ATHAM programme did not involve the parents and that "the school seems to have no idea how to involve the parents or address problems related to family background, which can be very serious." A school administrator from another school said that it was difficult to get the support from the students themselves as the students seemed to have an "attitude of not wanting to be involved" in the ATHAM programme and they did not give their cooperation. However, the school administrators, teachers and students who were involved in the planning and implementation of the ATHAM programme stated that with the support and active participation from SUHAKAM they were able to overcome the challenges in implementing the activities under the ATHAM programme.

The quantitative findings indicated that both the teachers (mean $=3.69$ ) and students (mean = 3.52) perceived that time factor was the foremost challenge in implementing the ATHAM programme. As for the other challenges, the teachers perceived in descending order of the mean value were lack of human rights knowledge (mean $=3.34$ ), inadequate skills in promoting ATHAM programme (mean $=3.26$ ) and finally the lack of support from the community (mean = 3.20). On the other hand, the perceptions of the students on the other challenges were different from the teachers as indicated in descending order of the mean value to be lack of support from the community (mean $=3.40$ ), stakeholders' inadequate skills in promoting ATHAM programme (mean $=3.36$ ), and finally the lack of knowledge on human rights (mean $=3.29$ ). More teachers (mean $=3.56)$ than students (mean $=$ 3.23) indicated that their school experienced no difficulties in implementing ATHAM programme.

On the whole, the findings on the challenges and constraints faced by the school administrators, teachers and students indicated that time factor was the foremost challenge faced by them. This could be the case as teachers are burdened with both academic and non-academic duties and responsibilities. In fact, the stress and heavy work burden of teachers in Malaysia was also acknowledged by the Deputy Minister of Education who announced that a working committee was established to study how teachers' workload could be reduced (The Borneo Post Online, 17 May 2012). Furthermore as an additional and relatively new programme not directly organised by the Ministry of Education, the other challenges faced by the teachers and students such as lack of human rights knowledge, skills in promoting human rights and support from other students needed to be recognised by the main organiser of the ATHAM programme, namely SUHAKAM.

\section{Overcoming the Challenges of the ATHAM Programme}

The teachers proposed that to overcome the challenges in implementing the ATHAM programme, it was important to establish a common practice for all schools such as setting up a special ATHAM unit by the state education department or district education office. They felt that it was important for schools to share their experiences and understanding on human rights which should be practised in all aspects, not only academically but also in students' behaviour and discipline. They suggested that such a special ATHAM unit would be able to provide support to all schools in creating a culture of human rights practices on a sustainable and long-term basis. In addition it was suggested that SUHAKAM should continue to be an active partner by going to the schools to assist them with the planning and implementation of the ATHAM programme. One teacher suggested 
that "SUHAKAM should inform all teachers the types of activities they want the school to help out". Another teacher voiced his concern on the sustainability of the programme which could "end up only in name".

In the questionnaires, the respondents were asked to indicate ways in overcoming the challenges of the ATHAM programme. Both teachers (mean $=4.40$ ) and students (mean $=4.27$ ) stated that the most agreeable way is that all school administrators, teachers and students in the school should practise human rights. While the teachers chose in descending mean value, the integration of human rights practices in the school discipline (mean $=4.37$ ) followed by cooperation among the school administrators, teachers and students in implementing the ATHAM programme, the students' perceived otherwise. The students were more in agreement on cooperation among the school administrators, teachers and students (mean $=4.21$ ) than integration of human right practices in school discipline (mean $=4.09$ ). As to SUHAKAM's direct involvement in the ATHAM programme in school, more teachers (mean $=4.08$ ) than students (mean $=3.90$ ) were in agreement to the statement. What is perhaps interesting to note is that more students (mean $=2.98$ ) than teachers (mean $=3.14$ ) indicated that no special programme needed to be organised in promoting human rights in their schools.

The overall results on ways to overcome the challenges in implementing the human rights practices programme in schools clearly indicated that all school administrators, teachers and students should implement the programme as part of their school life. The teachers perceived that the human rights practices should be incorporated in school's disciplinary actions was similarly expressed in their earlier response that the improvement of human rights practices in their schools should be in the students' behaviour. Furthermore as earlier discussed in this article, the local media highlighted delinquent behaviour of the students that violated human rights practices. In addition, the teachers indicated that SUHAKAM should be actively involved in implementing the programme in the schools as they expressed concern over their heavy work load in academic and non-academic duties.

\section{Conclusions}

The research study on the best practices of human rights or the ATHAM programme in Malaysian schools seemed to support the goals and methodology of the World Programme for Human Rights Education, that is adopting a whole-school approach to improve several aspects of the students' school life. In the case of Malaysian schools, human rights practices programme would be best implemented in the informal curriculum, that is in co-curriculum and the school management, particularly in the school discipline as well as creating a school environment that support quality education rather than in the school formal curriculum. This is because the formal curriculum is a centrally-planned curriculum by the Ministry of Education and schools do not have the flexibility to change the formal curriculum.

Whilst it is acknowledged that prior to the implementation of the ATHAM programme HRE were included in the school system, this research study found that the human rights practices particularly that related to the articles in the UDHR and CRC were not explicitly promoted and developed as part of the students' school life. It is with the implementation of the ATHAM programme that the teachers and students had greater awareness of their rights and the rights of others. In sum, as expressed by a teacher, "the learning of human rights lies with an individual for it entails honest self-examination, coming to understand and acknowledge the personal biases that everyone holds" and a student, "when I grow up, I want to be a lawyer and fight for human rights".

\section{References}

Borneo Post Online (17 May 2012). Measures seek to reduce teachers' workload - DPM. (available at http://www.theborneopost.com/2012/05/17/measures-seek-to-reduce-teachers-workloaddpm/\#ixzz2GAcwLQEn). [accessed 26 December 2012]. 
Corbin, J. \& Strauss, A. (2008). Basics of qualitative research: techniques and procedures for developing grounded theory ( $3^{\text {rd }}$ ed.). Thousand Oaks: Sage.

Creswell, J. W. (2008). Research design: qualitative, quantitative, and mixed methods approaches (3rd ed.). Thousand Oaks: Sage.

Department of Statistics Malaysia (2012). Population Statistics (Available at

http://www.statistics.gov.my/portal/index.php?lang=en). [accessed 20 August 2011].

Office of the United Nations High Commissioner for Human Rights (OHCHR). World programme for human rights education (2005-ongoing). (Available at

http://www2.ohchr.org/english/issues/education/training/programme.htm). [accessed 15 July 2011].

Siow, H. L. \& Chang, L. H. (2011). Education in Malaysia: development and transformation. In C. Brock \& L. P. Symaco (eds.). Education in Southeast Asia. Oxford: Symposium Books.

Suruhanjaya Hak Asasi Manusia Malaysia (SUHAKAM) (n.d.) Education and Promotion Working Group. (available at http://www.suhakam.org.my/ewg). [accessed 31 July 2011].

Suruhanjaya Hak Asasi Manusia Malaysia (SUHAKAM) (2009). Kertas konsep amalan terbaik hak asasi manusia di sekolah [Paper on concept on best practices of human rights in schools. Kuala Lumpur: SUHAKAM

Suruhanjaya Hak Asasi Manusia Malaysia (SUHAKAM). (n.d.) Human rights lesson plan for Southeast Asian schools. Kuala Lumpur: SUHAKAM

Suruhanjaya Hak Asasi Manusia Malaysia (SUHAKAM) (2006). Research on knowledge and practice of human rights in secondary schools. Kuala Lumpur: SUHAKAM

Suruhanjaya Hak Asasi Manusia Malaysia (SUHAKAM) (2005). Report of the roundtable discussion convention on the rights of the child. (available at http://www.suhakam.org.my/conf_forum_ wshop_report). [Accessed 31 July 2011].

Suruhanjaya Hak Asasi Manusia Malaysia (SUHAKAM) (n.d.). Report on access to education in Malaysia. (available at http://www.suhakam.org.my/conf_forum_wshop_report). [accessed 31 July 2011].

Suruhanjaya Hak Asasi Manusia Malaysia (SUHAKAM) (2006.). Human Rights Approach on the Millennium Development Goal - Goals 2: Achieve Universal Primary Education. (available at http://www.suhakam.org.my/). [accessed 26 December 2012].

Suruhanjaya Hak Asasi Manusia Malaysia (SUHAKAM) (n.d.) Universal Declaration of Human Rights. (available at http://www.suhakam.org.my). [accessed 31 July 2011].

Suruhanjaya Hak Asasi Manusia Malaysia (SUHAKAM) (n.d.) UN Convention on the rights of the child. (available at http://www.suhakam.org.my). [accessed 31 July 2011].

United Nations Education, Scientific and Cultural Organization (UNESCO) (2006). Plan of action world programme for human rights education first phase. New York \& Geneva: UNESCO.

United Nations Education, Scientific and Cultural Organization (UNESCO). Human rights education. (available at http://www.unesco.org/en/human-rights-education/). [accessed 15 July 2009]. 